\title{
Short-Term Regeneration Dynamics of Wyoming Big Sagebrush at Two Sites in Northern Utah
}

Author(s): Sara J. Germain, Rebecca K. Mann, http://

orcid.org/0000-0003-1472-7326Thomas A. Monaco and http://

orcid.org/0000-0001-7523-3368Kari E. Veblen

Source: Western North American Naturalist, 78(1):7-16.

Published By: Monte L. Bean Life Science Museum, Brigham Young University

URL: http://www.bioone.org/doi/full/10.3398/064.078.0103

BioOne (www.bioone.org) is a nonprofit, online aggregation of core research in the biological, ecological, and environmental sciences. BioOne provides a sustainable online platform for over 170 journals and books published by nonprofit societies, associations, museums, institutions, and presses.

Your use of this PDF, the BioOne Web site, and all posted and associated content indicates your acceptance of BioOne's Terms of Use, available at www.bioone.org/page/terms of use.

Usage of BioOne content is strictly limited to personal, educational, and non-commercial use. Commercial inquiries or rights and permissions requests should be directed to the individual publisher as copyright holder. 


\title{
Short-term regeneration dynamics of Wyoming big sagebrush at two sites in northern Utah
}

\author{
Sara J. Germain ${ }^{1}$, Rebecca K. Mann ${ }^{1,2}$, Thomas A. Monaco $^{3}$, and Kari E. Veblen ${ }^{1,2, *}$ \\ ${ }^{1}$ Department of Wildland Resources, Utah State University, Logan, UT 84322-5230 \\ ${ }^{2}$ Ecology Center, Utah State University, Logan, UT 84322-5205 \\ ${ }^{3}$ USDA, Agricultural Research Service, Forage and Range Research \\ Laboratory, Utah State University, Logan, UT 84322-6300
}

\begin{abstract}
Wyoming big sagebrush (Artemisia tridentata ssp. wyomingensis) is a widespread shrub across the western United States, and there is great interest among scientists and land managers in its ecology and conservation, particularly with regard to maintaining structural heterogeneity of sagebrush stands for wildlife habitat and livestock forage. Yet little is known about its short-term regeneration dynamics and the implications of those dynamics for changes in stand structure. We examined changes among sagebrush size classes across 3 years, as well as emergence of sagebrush from seed bank and seed rain samples at 2 sagebrush shrubland sites in northern Utah: a lower-density site (1.4 plants $\left./ \mathrm{m}^{2}, \mathrm{SE} 0.11\right)$ with no recent history of manipulation and a higher-density site $\left(1.9\right.$ plants $\left./ \mathrm{m}^{2}, \mathrm{SE} 0.21\right)$ that had recently been treated with herbicide to reduce sagebrush cover. On both sites, numbers of sagebrush plants in the largest size class decreased over the 3-year time period, while dead and medium-sized sagebrush plants increased. At the higher-density herbicide-treated site, this size class shift appeared to be driven by growth of small plants into the medium size class, likely associated with reductions in numbers of (and competition from) large plants. At the lowerdensity site, it appears that densities of large plants declined because the plants shrank in size, possibly due to herbivory. Sagebrush seed rain did not differ between fall and spring assessments. Forbs had the greatest representation in the seed bank, followed by grasses and then sagebrush, though the number of sagebrush seeds may be sufficient for seedling recruitment. These results illustrate that shifts among sagebrush size classes, especially transitions of small shrubs into the medium size class, may be a primary and immediate pathway of stand recovery, in addition to recruitment from seed. These findings underscore the importance of sagebrush stand structure to plant community health and may aid in anticipating responses to disturbances such as drought or herbivory.
\end{abstract}

Resumen.-La especie Artemisia tridentata ssp. wyomingensis es un arbusto ampliamente distribuido en el oeste de Estados Unidos. Existe gran interés por este arbusto entre los científicos y los administradores de tierras debido a su ecología y conservación, especialmente en lo que respecta al mantenimiento de su heterogeneidad estructural como hábitat silvestre y alimento para el ganado. Sin embargo, poco se sabe acerca de la dinámica de regeneración a corto plazo y las implicaciones en los cambios en sus estructuras. Durante tres años, examinamos los cambios entre las clases de tamaños de A. $t$. wyomingensis, así como el surgimiento de A. t. wyomingensis, proveniente de bancos y lluvias de semillas, en dos sitios de matorrales de A. t. wyomingensis al norte de Utah: un sitio de baja densidad (1.4 plantas $/ \mathrm{m}^{2}$, EE 0.11), sin historial reciente de manipulación, y un sitio de mayor densidad (1.9 plantas $/ \mathrm{m}^{2}$, EE 0.21 ) tratado recientemente con herbicidas para reducir la cobertura de A. $t$. wyomingensis. En ambos sitios, el número de plantas de A. $t$. wyomingensis de mayor tamaño, disminuyó al cabo de un período de tres años. Mientras que, la muerte de las plantas de A. t. wyomingensis de tamaño mediano incrementó. En los sitios de mayor densidad, tratados con herbicidas, el cambio en la clase de tamaño, fue promovida por el crecimiento de plantas pequeñas, dentro de la clase de tamaño mediano, probablemente asociado con reducciones en el número de (y la competencia entre) plantas grandes. En el sitio de menor densidad, la cantidad de plantas grandes disminuyó debido a su reducción en tamaño, posiblemente por herbivoría. La lluvia de semillas de $A$. $t$. wyomingensis no difirió entre los muestreos llevados a cabo en otoño y primavera. Las herbáceas fueron las de mayor presencia en el banco de semillas, seguido de las hierbas y finalmente A. t. wyomingensis, aunque esta última puede estar representada en cantidad suficiente para el reclutamiento de plántulas. Estos resultados demuestran que los cambios entre las clases de tamaños de A. t. wyomingensis, especialmente la transición de los arbustos de una clase de tamaño pequeña a mediana, pueden ser una vía primaria e inmediata para su recuperación, además del reclutamiento proveniente de semillas. Estos hallazgos enfatizan la importancia estructural de A. $t$. wyomingensis para la salud de la comunidad de las plantas y la anticipación de respuestas a los disturbios causador por sequías o herbivoría.

*Corresponding author: kari.veblen@usu.edu 
Wyoming big sagebrush (Artemisia tridentata ssp. wyomingensis) is a widespread dominant shrub across much of the Intermountain West. It is the foundational species of the sagebrush steppe, which provides critical habitat for numerous wildlife species, including the federally threatened Greater SageGrouse (Centrocercus urophasianus; Schroeder et al. 2004), Brewer's Sparrow (Spizella breweri; Knick and Rotenberry 2002), and pygmy rabbit (Brachylagus idahoensis; Rowland et al. 2006). These wildlife species, particularly sage-grouse, require shrub structural diversity for their habitat (Crawford et al. 2004, Dahlgren et al. 2006). While sagebrush density is known to dynamically shift over both short- and long-term periods even in the absence of anthropogenic disturbances (Anderson and Inouye 2001), little is known about changes in densities of particular size classes over time.

Managers often must balance structural diversity of sagebrush stands for wildlife habitat with alternative land uses, including grass production for domestic livestock forage (Noss et al. 1995, Davies et al. 2011). While it is clear that sagebrush populations can decline due to factors such as ungulate herbivory (Wambolt and Sherwood 1999) and wildfire (Davies et al. 2011), in some cases sagebrush can become overdominant and structurally homogeneous, typically due to inappropriate livestock grazing practices that reduce perennial herbaceous vegetation (Hanson and Stoddart 1940, Cooper 1953, Schlaepfer et al. 2014). Range managers throughout the 20th century have therefore attempted to thin sagebrush stands and increase understory herbaceous production by using controlled burning, mechanical treatments, or chemical herbicides (Pechanec et al. 1954, McIver and Brunson 2014).

Although many shrub reduction activities successfully reduce shrub abundance on the landscape in the short term (Wambolt and Payne 1986), some reports show that shrub control activities are short-lived or ineffective (McDaniel et al. 2005). Moreover, little information exists on how management interventions affect structural heterogeneity of sagebrush stands. The likelihood that management actions have unique effects on sagebrush of different sizes, leading to important structural changes-and potentially short-lived treatment effects - emphasizes the need for more research to examine drivers of local-scale sagebrush size structure dynamics within individual stands. In particular, more detailed information on natural changes in sagebrush size distributions over time, as well as how size distributions respond to management treatments, will provide insights into regeneration dynamics of this important species.

It is also unclear to what extent size distributions may be driven by recruitment of sagebrush seedlings from the seed bank. Sagebrush recruitment is known to be episodic and greater in wet years (Young et al. 1989, Maier et al. 2001, Perryman et al. 2001), and sagebrush seed banks are known to be short-lived (Young and Evans 1975, Wijayratne and Pyke 2012), suggesting that recruitment from seed may influence the effectiveness of shrub treatment methods. Though ample research exists describing (1) the conditions necessary for germination and establishment (e.g., controlled competitors, shallow planting depth; Meyer and Monsen 1992, Meyer 1994, Monsen and Stevens 2004) and (2) practical seed quality and seeding technology (Williams et al. 2002, Lambert 2005, Ott et al. 2017), little is known about short-term regeneration dynamics of sagebrush for either intact sagebrush stands or those that have been subject to reductions via management.

We investigated size class distributions of sagebrush plants in Wyoming big sagebrush communities in northern Utah that were managed for both livestock production and wildlife habitat. Our study included 2 sites representing common phases of sagebrush communities that were managed in different ways. The first site had high shrub density and was treated with a low rate of tebuthiuron, a soil-active chemical commonly used for reducing shrubs in the Intermountain West (Olson and Whitson 2002). The second site had lower initial shrub density and was therefore not treated. At each site, we tracked changes in sagebrush size classes for 3 years and also measured density of sagebrush seedlings emerging from seed rain traps and seed bank samples to assess the impact of management on these regeneration mechanisms.

We expected the high seed production of sagebrush (112-336 kg/ha per year; Tilley et al. 2017) to eliminate or drastically reduce any biologically meaningful differences in seed 
rain between the high-density and low-density sites and instead hypothesized that we would observe unique changes in densities per size class for established sagebrush plants. Specifically, at the high-density herbicide-treated site we expected to observe either (1) reduction of all shrub size classes, resulting in release of seedlings from the seed bank (sensu Young and Evans 1989, Perryman et al. 2001, Schlaepfer et al. 2014) or (2) greater mortality of larger shrubs than smaller shrubs from the soil-applied herbicide, resulting in release of surviving plants in smaller size classes and suppression of seedlings from the seed bank. Conversely, at the low-density site we expected few to no changes in size class distribution over the course of the short-term observation window due to the lack of management interventions and only moderate livestock grazing intensity.

\section{METHODS}

\section{Study Site}

Our study was conducted in the Wyoming Basin (Level III Ecoregion 18), Semiarid Bear Hills (Level IV Ecoregion 18d), in northeastern Utah (https://www.epa.gov/eco-research/ level-iii-and-iv-ecoregions-continental-united -states). The study area is a cattle ranch in northern Utah $\left(41.87000^{\circ} \mathrm{N}, 111.24000^{\circ} \mathrm{W}\right.$; average elevation $2225 \mathrm{~m}$ asl) located on an Upland Loam (Wyoming Big Sagebrush) Ecological Site (USDA-NRCS 2017). The soils are classified as Lonjon Silt Loam, which is moderately permeable, gravelly, and moderately deep. Mean annual precipitation ranges from 305 to $406 \mathrm{~mm}$, with average winter temperatures of $-5.3{ }^{\circ} \mathrm{C}$ and average summer temperatures of $15.9{ }^{\circ} \mathrm{C}$ (PRISM 2015). Common woody species are Wyoming big sagebrush (Artemisia tridentata Nutt. ssp. wyomingensis Beetle \& Young) and rubber rabbitbrush (Ericameria nauseosa [Pall. ex Pursh] G.L. Nesom \& Baird). Herbaceous vegetation is dominated by perennial grasses and forbs, including needle-and-thread grass (Hesperostipa comata [Trin. \& Rupr.] Barkworth), prairie Junegrass (Koeleria macrantha [Ledeb.] Schult.), silvery lupine (Lupinus argenteus Pursh.), and sulfur buckwheat (Eriogonum umbellatum Torr.). Plant nomenclature follows the USDA PLANTS Database (NRCS 2016).

\section{Study Design}

Within the study area, we investigated 2 site types that were similar in soils, vegetation, and landscape position but dissimilar with respect to sagebrush densities. Mean (SE) mature sagebrush densities were $1.4(0.11)$ and $1.9(0.21)$ plants $/ \mathrm{m}^{2}$ at the low- and highdensity sites, respectively. These values are similar to sagebrush density standards (i.e., $\geq 1$ plants $/ \mathrm{m}^{2}$ ) for reclaimed mine lands in Wyoming (Williams et al. 2002), as well as untreated and treated high-density stands in eastern Oregon (i.e., 1.0 and 0.5 plants $/ \mathrm{m}^{2}$, respectively; Davies et al. 2012). At the lowerdensity (LD) site, twenty 20 -m transects (minimum $15 \mathrm{~m}$ apart) were distributed throughout 2 areas, totaling approximately $15 \mathrm{ha}$. At the higher-density (HD) site, twenty 20-m transects (minimum $35 \mathrm{~m}$ apart) were distributed throughout a single area that spanned more than 200 ha. In fall 2012, prior to the initiation of our study, the HD site had been treated with a low application rate $(2.8 \mathrm{~kg} / \mathrm{ha})$ of a granular tebuthiuron 20P (Alligare LLC, Opelika, AL, USA) herbicide that targets woody plants.

In fall 2012 and summer 2014 and 2015, sagebrush densities were measured in 1-mwide belts created by holding a 1-m stick while walking adjacent to each of the 40 transects and counting sagebrush plants in the $20-\mathrm{m}^{2}$ area. Sagebrush plants were classified as large $(>30 \mathrm{~cm}$ high, main stem $>6.5 \mathrm{~mm}$ diameter, complex branching, rounded growth form, and evidence of flowering structures), medium $(7.6-30 \mathrm{~cm}$ high, main stem 3-6.5 mm diameter, minimal branching, and nonreproductive), small ( $<7.6 \mathrm{~cm}$ high, no branching, and nonreproductive), or dead. We did not determine age of sagebrush plants, but our large, medium, and small size classes roughly correspond to "large mature" (stems $>3 \mathrm{~cm}$ diameter), "juvenile" (>10 cm high, stems $<1 \mathrm{~cm}$ diameter), and "seedlings" $(<10 \mathrm{~cm}$ high), respectively, as described by Lesica et al. (2007).

Along each of the 40 transects, 5 seed rain (SR) traps were placed at 5-m intervals between 0 and $20 \mathrm{~m}$ (200 traps total) to capture seeds dispersed by gravity and wind. Based on methods of Schott (1995), traps were made by filling a $75-\mathrm{cm}^{2}$ funnel with medium gravel inside a plastic cup with drainage holes. Traps were then buried in the soil with a 1-cm lip above ground. Seed rain traps were deployed 
TABLE 1. Greenhouse trials conducted in this study, including collection dates, grow-out dates, and number of subsamples (each grown in its own pot) for a low-density sagebrush site (LD) and a high-density tebuthiuron-treated site (HD).

\begin{tabular}{|c|c|c|c|c|}
\hline Trial type & Collection date & Grow-out date & $\begin{array}{l}\text { No. of LD } \\
\text { subsamples }\end{array}$ & $\begin{array}{l}\text { No. of HD } \\
\text { subsamples }\end{array}$ \\
\hline Seed rain 1 (SR1) & November 2013 & June 2014 & 92 & 86 \\
\hline Seed rain 2 (SR2) & May 2014 & August 2014 & 99 & 96 \\
\hline Seed bank (SB) & June 2014 & September 2014 & 100 & 100 \\
\hline
\end{tabular}

in October 2013, and samples were collected from these traps twice (SR1 and SR2; Table 1). Samples were kept in plastic bags with a moist paper towel for transportation to the laboratory, where they were stored at $4{ }^{\circ} \mathrm{C}$ for 120 (SRI1) and 75 (SRI2) days, respectively. Seed bank (SB) samples were collected in June 2014 (Table 1) at each of the 200 seed trap locations. Each sample comprised three 5 -cm-long $\times 1$-cm-diameter soil cores combined in a bag, and all samples were cold stratified for 60 days.

Grow-out trials for SR1, SR2, and SB samples were conducted in summer/fall 2014 (Table 1) in a greenhouse on the Utah State University campus under ambient solar radiation with day and night air temperatures maintained at $70{ }^{\circ} \mathrm{C}$. In each trial, each subsample (Table 1) was grown in steam-sterilized loamy sand in its own sterile pot $\left(550 \mathrm{~cm}^{3}\right)$ that had been cut and fit with cheesecloth to prevent sand leakage. Pots were spatially randomized on a greenhouse bench. SR1 and SR2 samples were rinsed with water over a sieve, then vacuum filtered to remove soil and plant debris. A squirt bottle was then used to spray seeds onto the soil surface (SR1) or onto paper towel squares placed on the soil surface to prevent seed loss (SR2). SB samples were spread evenly and thinly across the soil surface. All pots were bottom-watered and the soil was kept saturated. We counted and identified all seedlings weekly for 30 days in each trial and removed seedlings at the time of identification to prevent double counting.

\section{Statistical Analyses}

For all analyses, subsample data were averaged for each transect $(n=20$ transects for each of the 2 sites), and transects were considered independent experimental units. We used nonparametric tests for all analyses because the data did not meet assumptions of normality and homogeneity of variance, even with transformation. For each of the 2 sites
(LD and HD), we performed 4 separate analyses of small, medium, large, and dead sagebrush densities to test for effects of year (2012, 2014, and 2015) using a Bonferroniadjusted alpha level $(\alpha=0.0125)$. Similarly, for each seed rain trial (SR1 and SR2), we tested for differences in seedling emergence density between the fall and spring sampling dates at each of the 2 sites. We used the Wilcoxon Signed-Rank method for these tests to account for potential serial correlation associated with repeated measures. For seed bank data at each site, we used the Wilcoxon RankSum method to test for pairwise differences among forb, grass, and sagebrush emergence within a given year, again using a Bonferroniadjusted alpha level $(\alpha=0.0167)$. Analyses were performed in $\mathrm{R}$ version 3.1.0 ( $\mathrm{R}$ Core Team 2014).

\section{REsults}

Although both HD and LD sites experienced declines of large sagebrush, the degree of loss at the HD site (89\% from 2012 to 2015) was greater than that at the LD site $(35 \%$ from 2012 to 2015) (Fig. 1, Table 2). The HD site also experienced a much greater decline from 2012 to 2014 than did the LD site $(80 \%$ and $31 \%$, respectively; Fig. 1, Table 2); only at the HD site did densities continue to decline into the final year (2015; Fig. 1, Table 2). At the HD site, densities of sagebrush in the smallest size class also declined by $99 \%$ from 2012 to 2015; the magnitude of this decline exceeded the magnitude of declines in all other size classes at either site. Declines at the LD site were nonsignificant (Fig. 1, Table 2).

In contrast, densities of sagebrush in the medium size class increased at both sites from 2012 to 2014 (2.2 and 4.4 times greater at the HD and LD sites, respectively; Fig. 1, Table 2). Densities of medium sagebrush appeared to be consistently higher at the HD site than at the LD site over the time frame of our 
Low density site

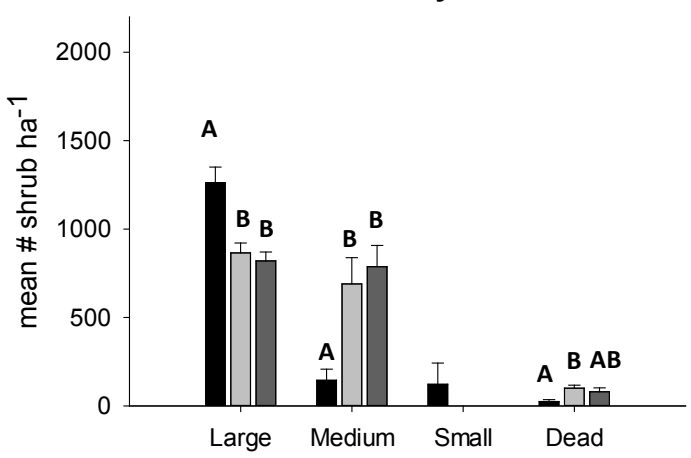

High density site

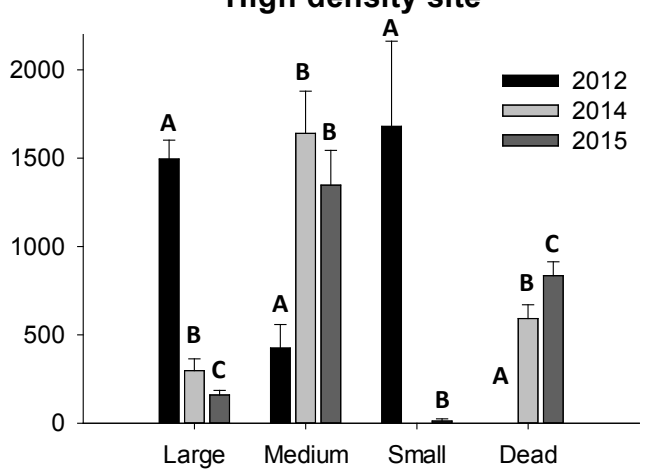

Fig. 1. Mean shrub densities ( $\pm 1 \mathrm{SE}$ ) for large, medium, small, and dead sagebrush plants over 3 years at each of 2 sites $(n=20$ for each site). One site had low densities of sagebrush, and one site had high densities of sagebrush and was treated with herbicide to reduce sagebrush in 2012. Shared letters indicate no statistically significant differences $(P<0.05)$ between years within a sagebrush category at a given site.

TABLE 2. Wilcoxon signed-rank test results for comparisons of sagebrush densities between years $(2012$, 2014, and 2015) across 20 transects at each of 2 sites (one site with low densities of sagebrush and one site with high densities of sagebrush that was also treated with herbicide to reduce sagebrush in 2012). Separate analyses were performed for small, medium, large, and dead sagebrush at each site. An asterisk (*) indicates significance at the 0.05 level following Bonferroni correction, and a plus symbol $(+)$ indicates significance at the 0.10 level. Statistical tests could not be performed at the low-density site for small shrubs in 2014 vs. 2015 because of too many zero values.

\begin{tabular}{|c|c|c|c|c|c|}
\hline & & \multicolumn{2}{|c|}{ Low sagebrush density } & \multicolumn{2}{|c|}{ High sagebrush density } \\
\hline & & $V$ statistic & $P$ & $V$ statistic & $P$ \\
\hline \multirow[t]{4}{*}{2012 vs. 2014} & Dead & 116.5 & $0.0012 *$ & 210 & $<0.0001 *$ \\
\hline & Large & 3 & $0.0001 *$ & 0 & $<0.0001 *$ \\
\hline & Medium & 207 & $0.0001 *$ & 200 & $0.0004 *$ \\
\hline & Small & 0 & 0.3711 & 0 & 0.0003 \\
\hline \multirow[t]{4}{*}{2014 vs. 2015} & Dead & 82.5 & 0.4653 & 2 & $0.0029 *$ \\
\hline & Large & 126.5 & 0.0728 & 134 & $0.0065 *$ \\
\hline & Medium & 45.5 & $0.0270+$ & 145.5 & 0.0440 \\
\hline & Small & - & - & 0 & 1 \\
\hline \multirow[t]{4}{*}{2012 vs. 2015} & Dead & 22 & 0.0572 & 0 & $<0.0001 *$ \\
\hline & Large & 205.5 & $0.0002 *$ & 210 & $<0.0001 *$ \\
\hline & Medium & 1 & $0.0001 *$ & 30 & $0.0054 *$ \\
\hline & Small & 3 & 0.3711 & 153 & $0.0003 *$ \\
\hline
\end{tabular}

study (Fig. 1). Densities of dead sagebrush increased from 2012 to 2014 at both sites (Fig. 1, Table 2). However, only at the HD site did increases continue into the final year, likely due in part to herbicide treatment; by 2015 , dead sagebrush accounted for $35 \%$ of all sagebrush at the HD site, compared to only $5 \%$ at the LD site.

Sagebrush seedling emergence from seed rain samples (SR1 and SR2) was similar for fall $(\bar{x}=2.1$ plants per pot $)$ and spring $(\bar{x}=$ 2.6 plants per pot) samples at both $\mathrm{LD}(V=$ $71, P=0.22)$ and $\operatorname{HD}(V=56, P=0.55)$ sites (Fig. 2). Emergence from the seed bank indicated that forb emergence at each of the 2 sites was greater than emergence of either grasses (3.7 times greater in HD, 3.8 times greater in LD) or sagebrush (7.9 times greater in HD, 6.6 times greater in LD) (Fig. 3, Table 3).

\section{Discussion}

Changes to the size structure of sagebrush stands can occur via multiple pathways, due to both natural processes and management actions (Beck et al. 2009, Mitchell et al. 2017). For example, in the absence of largescale disturbance, size structure of sagebrush stands is uneven, indicative of seedling recruitment from the seed bank (Lesica et al. 


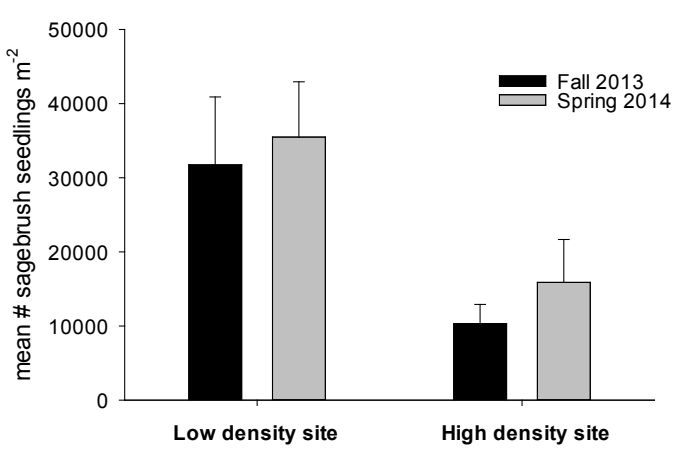

Fig. 2. Mean number of emergent sagebrush seedlings per square meter $( \pm 1 \mathrm{SE})$ during greenhouse grow-out trials of seeds collected from $75-\mathrm{cm}^{2}$ seed traps at 2 times of year at 2 sites $(n=20$ for each site). One site had low densities of sagebrush, and one site had high densities of sagebrush and was treated with herbicide to reduce sagebrush in 2012.

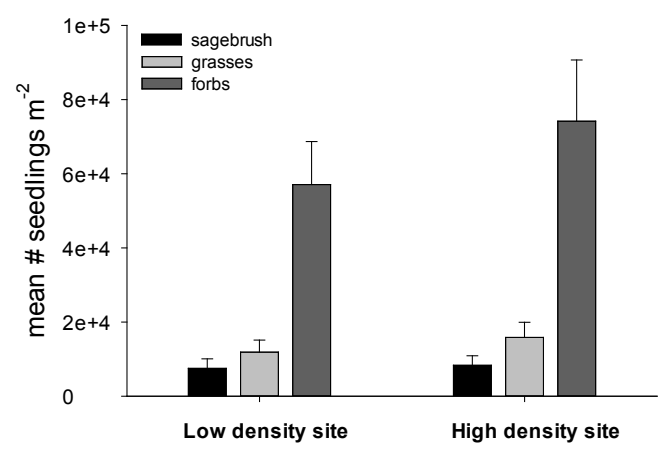

Fig. 3. Mean seedling emergence $( \pm 1 \mathrm{SE} ; n=20)$ during greenhouse grow-out trials of sagebrush, grass, and forb seeds collected from seed banks at 2 sites $(n=20$ for each site, where each sample value is the mean of five $12-\mathrm{cm}^{3}$ subsamples). One site had low densities of sagebrush, and one site had high densities of sagebrush and was treated with herbicide to reduce sagebrush in 2012.

TABLE 3. Wilcoxon rank-sum test results for comparisons of sagebrush, grass, and forb densities in the seed bank across 20 transects at each of 2 sites (one site with low densities of sagebrush and one site with high densities of sagebrush that was also treated with herbicide to reduce sagebrush in 2012). An asterisk (*) indicates significance at the 0.05 level following Bonferroni correction.

\begin{tabular}{lccccr}
\hline & \multicolumn{2}{c}{ Low sagebrush density } & & \multicolumn{2}{c}{ High sagebrush density } \\
\cline { 2 - 3 } & $W$ statistic & & & W statistic & $P$ \\
\hline Sagebrush vs. grass & 234 & 0.3075 & & 242 & 0.2172 \\
Grass vs. forb & 313 & $0.0017 *$ & & 318 & $0.0011 *$ \\
Sagebrush vs. forb & 69.5 & $0.0002^{*}$ & & 58 & $<0.0001 *$ \\
\hline
\end{tabular}

2007). Alternately, recovery from fire, as well as the more rapid recovery sometimes observed following herbicide treatment, is attributed primarily to seed rain from surviving mature sagebrush (Johnson and Payne 1968, Bartolome and Heady 1978, Baker 2006). Our results suggest that shifts among size classes of established sagebrush are another important pathway for changes in stand structure in both minimally managed low-density and more intensively managed higher-density sagebrush stands.

We found that densities of medium-sized sagebrush plants increased over time at both sites (sensu Owens and Norton 1990). The increase of medium plants contributed to increased structural heterogeneity in the lowdensity site, which was dominated by large sagebrush at the onset of our study. Sagebrush germinants did not recruit into the small size class at rates detectable in our study at either site. At the high-density site, this lack of recruitment into the small size class, combined with mortality of large shrubs, likely contributed to our observation of decreased vertical structural diversity (i.e., medium shrubs dominating the stand) and increased horizontal structural diversity (i.e., interspersed live shrub patches and dead shrub gaps).

Over the 3.5-year time frame of our study, densities of medium-sized shrubs increased regardless of differences in management history and initial stand densities between sites. However, the mechanisms responsible for structural changes appeared to differ between the 2 sites. At the lower-density site, where sagebrush had not been treated with herbicide, the increase in medium shrubs was only partly explained by the decrease in small shrubs; in other words, the loss of small shrubs via growth into the medium size class could not fully (numerically) account for the overall increase in medium shrubs at that site. Because numbers of dead sagebrush similarly could not numerically account for losses of plants in the large sagebrush category, we 
conclude that larger sagebrush were reduced in size, thereby accounting for the remaining increases to the medium size class we observed. This could have been caused by herbivory from elk (Cervus canadensis) and mule deer (Odocoileus hemionus), which can reduce canopy cover and induce mortality of individual sagebrush plants, thereby affecting size class distributions (Wambolt and Sherwood 1999, Veblen et al. 2015). Alternatively, reductions in shrub stature can be caused by other mechanical factors, such as breakage from heavy snow deposition on branches or trampling by livestock and large wildlife (Owens and Norton 1992). Although we did not explicitly test any of these mechanisms, we found that a low-density, moderately grazed site without prior management intervention became more structurally diverse over the short term; these results contrast with commonly observed long-term patterns of sagebrush stands becoming more structurally homogeneous with reduced herbaceous understory (Hanson and Stoddart 1940, Cooper 1953, Avirmed et al. 2015).

A greater understanding of changes in sagebrush size class transitions following active management will provide insights into regeneration mechanisms needed to develop better restoration strategies (Chambers and Wisdom 2009, Schlaepfer et al. 2014). The results from our higher-density site that had been treated with herbicide indicate that as densities of small and large sagebrush declined, medium-statured and dead sagebrush showed a roughly proportional increase. These results suggest that small sagebrush plants transitioned into the medium size class, while large sagebrush plants died. The significant loss of live, large sagebrush plants could have thereby released smaller sagebrush from competition and allowed them to grow into the medium size class. This result is not unexpected given the greater soil resource availability that probably followed the substantial tebuthiuron-driven mortality of large sagebrush (sensu Murray 1988, McDaniel et al. 2005). The increase in the medium-sized plant category also may have been due to higher survival probability, since medium plants may have experienced less trampling mortality from grazers than smaller plants (Owens and Norton 1990). These findings illustrate that recovery within sagebrush stands-specifically fol- lowing herbicide treatment, but potentially extending to other types of disturbances that reduce large sagebrush-may depend on the number of surviving small sagebrush that are able to grow into larger size classes following disturbance, not just recruitment from seed.

The relatively low representation of sagebrush in the seed bank that we observed highlights the importance of established, small sagebrush plants for stand recovery. Relative abundance of sagebrush seeds in the seed bank can be highly variable in sagebrush sites (Allen et al. 2008, Pekas and Schupp 2013) depending on disturbance history, and sagebrush seeds may even be absent in the case of invasive annual grass dominance (Hassan and West 1986, Humphrey and Schupp 2001). Because our sites were not invaded by annual grasses, we expected to observe a high representation of sagebrush in the seed bank (i.e., Hassan and West 1986, Gunnell 2009). Instead, we found a higher contribution of forbs relative to either sagebrush or grasses. These results suggest that forb abundance might be expected to increase alongside the increasing numbers of medium-sized shrubs we observed at both sites since seed bank can be representative of aboveground plant functional group abundance (Pekas and Schupp 2013). Further studies need to be conducted to (1) inspect seed banks over multiple time periods, (2) determine whether greater numbers of forbs in the seed bank can result in greater forb populations, and (3) determine to what extent plant establishment is limited by factors such as competition, drought, or herbivory (Avirmed et al. 2015, Rottler et al. 2018). Furthermore, it is important to investigate any negative effects of residual tebuthiuron on aboveground abundance of forbs (sensu Scifres and Mutz 1978, Britton and Sneva 1981). Because tebuthiuron is absorbed by plant roots and transported to leaves (Chang and Stritzke 1977, Whisenant and Clary 1987, Johnsen and Morton 1989), residual tebuthiuron in the soil may have negative effects on forbs (and shrubs) once they are established.

Seed production of sagebrush occurs primarily during fall months (Hassan and West 1986), rendering our observation of no differences between fall and spring seed rain sampling periods somewhat unexpected. Our results suggest that sagebrush seeds remain on flowering stems and that seed dispersal 
continues until at least 6 months after seed production. Nonetheless, rates of seed rain at both sites occurred within a range similar to sagebrush stands elsewhere (West and Durham 1991, Landeen 2015). Although sagebrush recruitment is typically not limited by seed production (Schlaepfer et al. 2014), it is highly episodic (Perryman et al. 2001), responsive to rainfall (Frischknecht and Harris 1968), and negatively influenced by competition from resident plants (Blaisdell 1949, Gunnell et al. 2010). This suggests that under adequate field conditions even very few viable seeds may be enough for sagebrush recruitment. This is an important consideration for recruitment not only in undisturbed areas that may be of conservation concern but also in herbicidetreated areas where the goal is to reduce shrubs. Further research should determine what level of seed production is sufficient for increasing sagebrush populations from seed, such as the recommended seeding rate of $1.1-2.2 \mathrm{~kg} / \mathrm{ha}$ of pure live seed for establishing sagebrush in rangeland seedings (Jensen et al. 2001).

The high seed rain and increased densities of medium-sized sagebrush we observed following tebuthiuron treatment may explain why management activities aimed at reducing overall shrub densities often see short-lived results. Depending on management objectives, however, proliferation of younger, medium-sized shrubs and the associated increase in structural heterogeneity of sagebrush stands may be desirable. For instance, wildlife such as sage-grouse often require shrub structural diversity to address their various needs: large shrubs are required for shelter, younger shrubs with active leader growth are required for winter browse, and shrub-free patches that open niches for herbaceous plant growth and associated insects provide crucial nutrients for young chicks (Crawford et al. 2004, Dahlgren et al. 2006). At both our low- and high-density sites, the persistence of some large shrubs with a burgeoning medium size class is likely to contribute positively to sage-grouse habitat. Additionally, the structural changes we observed at the herbicide-treated high-density site, including creation of shrub-free patches (i.e., from dead shrubs) and higher densities of younger shrubs, represent potential mechanisms by which low-rate tebuthiuron application may benefit sage-grouse population habitat (Crawford et al. 2004, Dahlgren et al. 2006).

\section{Conclusions}

A variety of ecological drivers can be responsible for changes to the size structure of sagebrush stands. Our results are not inconsistent with previous studies indicating the importance of seed rain from surviving sagebrush (Johnson and Payne 1968, Bartolome and Heady 1978, Baker 2006) because the clearest, most immediate driver of sagebrush structural changes in our study appeared to be transitions among size classes of surviving plants. In undisturbed low-density sites, herbivory or other mechanical damage shifted shrub densities toward medium-sized plants, whereas transitions of small shrubs into the medium size class (associated with mortality of large plants) appeared to be a primary pathway of recovery in high-density disturbed areas treated by herbicide. Size class diversity may therefore be an important component of sagebrush stand resilience following disturbance (Ellsworth et al. 2016) that may enable resident plants to respond to shifting resource availability and recruitment opportunities in the wake of management action or natural disturbance. Future research is needed to explore how size class variation could indicate sagebrush stand resilience to disturbance and contribute to habitat characteristics needed by endemic wildlife.

\section{ACKNOWLEDGMENTS}

Funding was provided by the Summer Undergraduate Research and Creative Opportunities (SURCO) program and the Department of Wildland Resources, Utah State University; NRCS CIG; Utah Agricultural Experiment Station; and the USDA-ARS Forage and Range Research Lab in Logan, Utah. We thank Monty Weston for use of the study site, Justin Williams and Joe Lamb for field assistance, and John Stevens for assistance with statistical analyses. This research was approved as Utah Agricultural Experiment Station journal paper number 8848 .

\section{Literature Cited}

Allen, E.A., J.C. Chambers, and R.S. NowaK. 2008. Effects of a spring prescribed burn on the soil seed bank in sagebrush steppe exhibiting pinyon-juniper 
expansion. Western North American Naturalist 68: $265-277$.

Anderson, J.E., AND R.S. InOUye. 2001. Landscape-scale changes in plant species abundance and biodiversity of a sagebrush steppe over 45 years. Ecological Monographs 71:531-556.

Avirmed, O., W.K. Lauenroth, I.C. Burke, and M.L. MobLey. 2015. Sagebrush steppe recovery on 30-90year-old abandoned oil and gas wells. Ecosphere $6: 1-10$.

BAKER, W.L. 2006. Fire and restoration of sagebrush ecosystems. Wildlife Society Bulletin 34:177-185.

Bartolome, J.W., and H.F. Heady. 1978. Ages of big sagebrush following brush control. Journal of Range Management 31:403-406.

Beck, J.L., J.W. Connelly, And K.P. ReEse. 2009. Recovery of Greater Sage-Grouse habitat features in Wyoming big sagebrush following prescribed fire. Restoration Ecology 17:393-403.

BlaisDell, J.P. 1949. Competition between sagebrush seedlings and reseeded grasses. Ecology 30:512-519.

BRitTon, C.M., AND F.A. SNEva. 1981. Effects of tebuthiuron on western juniper. Journal of Range Management 34:30-32.

Chambers, J.C., and M.J. Wisdom. 2009. Priority research and management issues for the imperiled Great Basin of the western United States. Restoration Ecology 17:707-714.

Chang, S.S., and J.F. STRITZKe. 1977. Sorption, movement, and dissipation of tebuthiuron in soils. Weed Science 25:184-187.

Cooper, H.W. 1953. Amounts of big sagebrush in plant communities near Tensleep, Wyoming, as affected by grazing treatment. Ecology 34:186-189.

Crawford, J.A., R.A. Olson, N.E. West, J.C. Mosley, M.A. Schroeder, T.D. Whitson, R.F. Miller, M.A. GREGG, AND C.S. BoYD. 2004. Ecology and management of sage-grouse and sage-grouse habitat. Journal of Range Management 57:2-19.

Dahlgren, D.K., R. Chi, and T.A. Messmer. 2006. Greater Sage-Grouse response to sagebrush management in Utah. Wildlife Society Bulletin 34:975-985.

Davies, K.W., J.D. Bates, AND A.M. Nafus. 2012. Mowing Wyoming big sagebrush communities with degraded herbaceous understories: has a threshold been crossed? Rangeland Ecology and Management 65:498-505.

Davies, K.W., C.S. Boyd, J.L. Beck, J.D. Bates, T.J. SvejCAR, AND M.A. GREGG. 2011. Saving the sagebrush sea: an ecosystem conservation plan for big sagebrush plant communities. Biological Conservation 144:2573-2584.

Ellsworth, L.M., D.W. Wrobleski, J.B. Kauffman, and S.A. ReIS. 2016. Ecosystem resilience is evident 17 years after fire in Wyoming big sagebrush ecosystems. Ecosphere 7:e01618.

FrischKneCht, N.C., AND L.E. HARRIs. 1968. Grazing intensities and systems on crested wheatgrass in central Utah: response of vegetation and cattle. Technical Bulletin No. 1388. U.S. Department of Agriculture, Forest Service.

GunNeLL, K.L. 2009. Seed banks of sagebrush communities seeded with crested wheatgrass. Master's thesis, Utah State University, Logan, UT.

Gunnell, K.L., T.A. Monaco, C.A. Call, and C.V. RanSOM. 2010. Seedling interference and niche differentiation between crested wheatgrass and contrasting native Great Basin species. Rangeland Ecology and Management 63:443-449.

Hanson, W.R., and L.A. Stoddart. 1940. Effects of grazing upon bunch wheatgrass. Journal of the American Society of Agronomy 32:278-289.

Hassan, M.A., and N.E. West. 1986. Dynamics of soil seed pools in burned and unburned sagebrush semideserts. Ecology 67:269-272.

Humphrey, L.D., AND E.W. Schupp. 2001. Seed banks of Bromus tectorum-dominated communities in the Great Basin. Western North American Naturalist 61:85-92.

Jensen, K.B., W.H. Horton, R. Reed, and R. WhiteSIDES. 2001. Intermountain planting guide. AG Report 510, Utah State University Extension Publications, Logan, UT. 104 pp.

Johnsen, T.N., And H.L. MorTon. 1989. Tebuthiuron persistence and distribution in some semiarid soils. Journal of Environmental Quality 18:433-438.

Johnson, R.J., AND G.F. PaYne. 1968. Sagebrush reinvasion as affected by some environmental influences. Journal of Range Management 21:209-212.

KNiCK, S.T., AND J.T. RotenberRy. 2002. Effects of habitat fragmentation on passerine birds breeding in Intermountain shrubsteppe. Studies in Avian Biology 25:131-141.

LAmberT, S.M. 2005. Seeding considerations in restoring big sagebrush habitat. Pages 75-80 in N.L. Shaw, M. Pellant, and S.B. Monsen, editors, Sage-grouse habitat restoration symposium proceedings. RMRS-P-38, U.S. Department of Agriculture, Forest Service, Rocky Mountain Research Station, Fort Collins, CO.

LANDEEN, M.L. 2015. Mountain big sagebrush (Artemisia tridentata spp. vaseyana) seed production. Master's thesis, Brigham Young University, Provo, UT.

Lesica, P., S.V. CoOper, and G. KudRay. 2007. Recovery of big sagebrush following fire in southwest Montana. Rangeland Ecology and Management 60: 261-269.

Maier, A.M., B.L. Perryman, R.A. Olson, and A.L. HILD. 2001. Climatic influences on recruitment of 3 subspecies of Artemisia tridentata. Journal of Range Management 54:699-703.

McDaniel, K.C., L.A. Torell, and C.G. Ochoa. 2005. Wyoming big sagebrush recovery and understory response with tebuthiuron control. Rangeland Ecology and Management 58:65-76.

McIver, J., AND M. Brunson. 2014. Multidisciplinary, multisite evaluation of alternative sagebrush steppe restoration treatments: the SageSTEP Project. Rangeland Ecology and Management 67:435-439.

Meyer, S.E. 1994. Germination and establishment ecology of big sagebrush: implications for community restoration. Pages 244-251 in Proceedings-ecology and management of annual rangelands. General Technical Report INT-313, USDA Forest Service, Intermountain Research Station, Ogden, UT.

Meyer, S.E., ANd S.B. Monsen. 1992. Big sagebrush germination patterns: subspecies and population differences. Journal of Range Management 45:87-93.

Mitchell, R.M., J.D. BaKker, J.B. Vincent, and G.M. DAVIES. 2017. Relative importance of abiotic, biotic, and disturbance drivers of plant community structure in the sagebrush steppe. Ecological Applications 27:756-768.

Monsen, S.B., And R. Stevens. 2004. Seedbed preparation and seeding practices. Pages 121-154 in S.B. 
Monsen, R. Stevens, N.L. Shaw, editors, Restoring western ranges and wildlands. General Technical Report RMRS-GTR-136-vol-1, USDA Forest Service, Rocky Mountain Research Station, Fort Collins, CO.

MurRaY, R.B. 1988. Response of three shrub communities in southeastern Idaho to spring-applied tebuthiuron. Journal of Range Management 41:16-22.

[NRCS] Natural Resources Conservation Service. 2016. The PLANTS database. National Plant Data Team, Greensboro, NC; [accessed 8 June 2016]. http://plants.usda.gov

Noss, R.F., E.T. LARoe III, AND J.M. SCOTT. 1995. Endangered ecosystems of the United States: a preliminary assessment of loss and degradation. National Biological Service Biological Report 28, United States Department of the Interior, Washington, DC.

Olson, R.A., AND T.D. Whitson. 2002. Restoring structure in late-successional sagebrush communities by thinning with tebuthiuron. Restoration Ecology 10:146-155.

OtT, J.E., R.D. Cox, AND N.L. SHaW. 2017. Comparison of postfire seeding practices for Wyoming big sagebrush. Rangeland Ecology and Management 70: $625-632$.

Owens, M.K., and B.E. Norton. 1990. Survival of juvenile basin big sagebrush under different grazing regimes. Journal of Range Management 43:132-135.

Owens, M.K., AND B.E. NORTON. 1992. Interactions of grazing and plant protection on basin big sagebrush (Artemisia tridentata ssp. tridentata) seedling survival. Journal of Range Management 45:257-262.

Pechanec, J.F., A.P. Plummer, J.H. Robertson, and A.C. Hull JR. 1954. Agricultural Handbook No. 277, U.S. Department of Agriculture, Washington, DC. 40 pp.

Pekas, K.M., AND E.W. Schupp. 2013. Influence of aboveground vegetation on seed bank composition and distribution in a Great Basin Desert sagebrush community. Journal of Arid Environments 88:113-120.

Perryman, B.L., A.M. Maier, A.L. Hild, and R.A. Olson. 2001. Demographic characteristics of 3 Artemisia tridentata Nutt. subspecies. Journal of Range Management 54:166-170.

PRISM. 2015. 800-m Climate Normals (1981-2010). PRISM Climate Group, Oregon State University, Corvallis, OR.

R CoRe TEam. 2014. R: a language and environment for statistical computing. R Foundation for Statistical Computing, Vienna, Austria. http://www.R-project.org

Rottler, C.M., I.C. Burke, K.A. PalmQuist, J.B. BradFORD, AND W.K. Lauenroth. 2018. Current reclamation practices after oil and gas development do not speed up succession or plant community recovery in big sagebrush ecosystems in Wyoming. Restoration Ecology 26:114-123.

Rowland, M.M., M.J. Wisdom, L.H. Suring, and C.W. MEINKE. 2006. Greater Sage-Grouse as an umbrella species for sagebrush-associated vertebrates. Biological Conservation 129:323-335.

Schlaepfer, D.R., W.K. Lauenroth, and J.B. Bradford. 2014. Natural regeneration processes in big sagebrush (Artemisia tridentata). Rangeland Ecology and Management 67:344-357.
SchotT, G.W. 1995. A seed trap for monitoring the seed rain in terrestrial communities. Canadian Journal of Botany 73:794-796.

Schroeder, M.A., C.L. Aldridge, A.D. Apa, J.R. Bohne, C.E. Braun, S.D. Bunnell, J.W. Connelly, P.A. Deibert, S.C. Gardner, M.A. Hilliard, et al. 2004. Distribution of sage-grouse in North America. Condor 106:363-376.

SCIFres, C.J., AND J.L. Mutz. 1978. Herbaceous vegetation changes following applications of tebuthiuron for brush control. Journal of Range Management 31:375-378

Tilley, D.J., D. Ogle, L. St. John, and B. Benson. 2017. Plant guide: big sagebrush. United States Department of Agriculture, Natural Resource Conservation Service, Idaho State Office, Boise, ID; [accessed 12 June 2017]. https://plants.usda.gov/plantguide/pdf/ pg artr2.pdf

USDA-NRCS. 2017. The Ecological Site Information System. [Accessed 28 June 2017]. https://esis.sc .egov.usda.gov

Veblen, K.E., K.C. Nehring, C.M. McGlone, and M.E. Ritchie. 2015. Contrasting effects of different mammalian herbivores on sagebrush plant communities. PLOS ONE 10:e0118016.

Wambolt, C.L., And G.F. Payne. 1986. An 18-year comparison of control methods for Wyoming big sagebrush in southwestern Montana. Journal of Range Management 39:314-319.

Wambolt, C.L., and H.W. Sherwood. 1999. Sagebrush response to ungulate browsing in Yellowstone. Journal of Range Management 52:363-369.

West, N.E., AND S. Durham. 1991. Seed rain on and near a coal stripmine in southwestern Wyoming. Proceedings of the 1991 National Meeting of the American Society for Surface Mining and Reclamation, Durango, CO. 14-17 May 1991.

Whisenant, S.G., AND W.P. CLARY. 1987. Tebuthiuron distribution in soil following application of pellets. Journal of Environmental Quality 16:397-402.

Wijayratne, U.C., AND D.A. PYKE. 2012. Burial increases seed longevity of two Artemisia tridentata (Asteraceae) subspecies. American Journal of Botany 99: $438-447$.

Williams, M.I., G.E. Schuman, A.L. Hild, and L.E. VICKLUND. 2002. Wyoming big sagebrush density: effects of seeding rates and grass competition. Restoration Ecology 10:385-391.

YounG, J.A., AND R.A. Evans. 1975. Germinability of seed reserves in a big sagebrush community. Weed Science 23:358-364.

YounG, J.A., AND R.A. Evans. 1989. Dispersal and germination of big sagebrush (Artemisia tridentata) seeds. Weed Science 37:201-206.

Young, J.A., R.A. Evans, and D.E. Palmouist. 1989. Big sagebrush (Artemisia tridentata) seed production. Weed Science 37:47-53.

Received 24 October 2016

Revised 6 October 2017

Accepted 7 November 2017

Published online 17 April 2018 